\title{
Acid Glycohydrolases in rat spermatocytes, spermatids and spermatozoa: enzyme activities, biosynthesis and immunolocalization
}

\author{
Aida Abou-Haila ${ }^{1}$ and Daulat R.P. Tulsiani ${ }^{2 *}$ \\ ${ }^{1}$ UFR Biomédicale, Universite René Descartes, 45 rue des Saints-Pères, 75270 Paris, Cedex 06, France, Email: aida.abou- \\ haila@biomedicale.univ-paris5.fr ${ }^{2}$ Departments of Obstetrics \& Gynecology and Cell Biology, Vanderbilt University School of \\ Medicine, Room D-3243 MCN, Nashville, TN 37232-2633, USA, Fax: 615/322-4358, Email: \\ daulat.tulsiani@mcmail.vanderbilt.edu *To whom correspondence should be addressed.
}

Submitted: April 19, 2001; Accepted: November 19, 2001; Published December 3, 2001

Indexing terms: Sperm acrosome, male germ cells, $\beta$-D-galactosidase, acrosmal glycohydrolases, mammalian fertilization

Abbreviations: MEM, minimum essential medium; BSA, bovine serum albumin; PBS, phosphate buffered saline; SDS, sodium dodecyl sulphate; PAGE, polyacrylamide gel electrophoresis; PNP, p-nitrophenyl; EKRB, enriched Krebs-Ringer bicarbonate

\begin{abstract}
Mammalian sperm acrosomes contain several glycohydrolases that are thought to aid in the dispersion and digestion of vestments surrounding the egg. In this study, we have used multiple approaches to examine the origin of acrosome-associated glycohdyrdolases. Mixed spermatogenic cells, prepared from rat testis, were separated by unit gravity sedimentation. The purified germ cells (spermatocytes [SC], round spermatids [RS], and elongated/condensed spermatids $[\mathrm{E} / \mathrm{CS}]$ ) contained several glycohydrolase activities. Metabolic labeling in the cell culture, immunoprecipitation, and autoradiographic approaches revealed that $\beta$-D-galactosidase was synthesized in $\mathrm{SC}$ and $\mathrm{RS}$ in $88 / 90 \mathrm{kDa}$ forms which undergo processing in a cell-specific manner. Immunohistochemical approaches demonstrated that the enzyme was localized in Golgi membranes/vesicles, and lysosome-like structures in $\mathrm{SC}$ and RS, and forming/formed acrosome of E/CS.
\end{abstract}

\section{INTRODUCTION}

Many, if not all, mammalian cells contain a unique class of cytoplasmic (electron dense) organelles termed lysosomes $(1,2)$. These are membrane limited bag-like structures filled with acid hydrolases, and normally function in intracellular digestion of endogenous and exogenous substrates. Mammalian spermatozoa have no lysosomes, but contain sac-like structures surrounded by inner and outer membranes termed acrosomes (3). The sperm acrosome resembles a cellular lysosome in several ways, including their origin $(3,4)$. The two organelles contain many common enzymes, such as acid glycohydrolases, proteases, esterases, acid phosphatases, and aryl sulphatases
$(1,3,4)$. The acrosome contains a host of glycohydrolases with catalytic and immunological properties similar to the enzymes present within the lysosome. These enzymes are exo-glycohydrolases and function by cleaving specific terminal glycosyl residues from glycoproteins and glycolipids $(4,5)$ with a high substrate specificity.

Spermatozoa released from the seminiferous tubules (testis) are terminally differentiated cells with no known synthetic acitivity. Their components are synthesized in the spermatogenic cells during spermatogenesis. Since glycohydrolases are thought to aid in penetration of the zona pellucida, the extracellular coat that surrounds the mammalian egg, it was of interest to quantify these enzymes in purified germ cells and spermatozoa and examine their synthesis and localization. The procedures described below are based on two recent reports from our laboratories $(6,7)$.

\section{MATERIALS AND METHODS}

\section{Materials}

Adult male Sprague-Dawley rats (8-10 weeks old) were housed in our animal facilities under 16 light: 8 dark conditions with free access to food and water. The animals were either anesthesized or sacrificed by $\mathrm{CO}_{2}$ asphyxiation. All $p$-nitrophenyl (PNP)-glycopyranoside substrates, goldlabeled $(10 \mathrm{~nm})$ anti-rabbit (IgG) goat $\mathrm{IgG}$ fraction, fluorescein-labeled affinity-purified anti-rabbit ( $\mathrm{IgG})$ goat IgG fraction (1.5 mg protein/ml), DNase I (Type II), trypsin (type III), soybean trypsin inhibitor, and poly-L-lysine were from Sigma Chemical Co. (St. Louis, MO); collagenase (CSL-1) was from Worthington Biochemicals (Freehold,

s@ 2001Biological Procedures Online. All rights reserved. Paper-based copying and internal distribution permitted for educational or non-profit purposes. Printing for personal use permitted. Electronic copying, storage or redistribution prohibited. 
NJ). The Sta-Put cell separation apparatus was made by Proscience (Johns Scientific, Toronto, Canada) and consists of a linear gradient marker (2 flasks with double glass outlets), a cell loading chamber with $20 \mathrm{ml}$ syringe attached by silicone tubing to a three way T-bore stopcock (T-valve) and a sedimentation chamber with a micrometering flow valve at the base connected by another tube to the T-valve. A baffle is centered in the bottom of the chamber to avoid aggregation of cells during a high flow rate loading. A fraction collector equipped with a drop counter and a solenoid (to stop the flow during tube changes) is connected by silicone tubing to the micrometering flow valve. A sedimentation chamber of $18 \mathrm{~cm}$ diameter can be loaded with $1200 \mathrm{ml}$ of $2-4 \%$ BSA gradient and allow the separation of 5-6 × $10^{8}$ germ cells. Seventy micrometer nylon mesh was from Spectrum (Laguna Hills, CA). All electrophoretic reagents were from Bio-Rad Laboratories (Richmond, CA). NCS solubilizer and ${ }^{14} \mathrm{C}$-labeled standard marker proteins from Amersham. Reagents used for the isolation of testicular germ cells, including stock amino acids (essential and non-essential), L-glutamine, sodium pyruvate, penicillin and streptomycin (100 X) were from GIBCO BRL (Grand Island, NY). Media used for culturing of spermatogenic cells was derived from the protocol of Grootgoed et al. (8) and contained minimum essential medium (MEM, GIBCO), supplemented with $0.4 \%$ BSA, non-essential amino acids, antibiotics (100 units penicillin/ml; $0.1 \mathrm{mg}$ streptomycin $/ \mathrm{ml}, 1 \mu \mathrm{g}$ fungizone $/ \mathrm{ml}$ ), $5 \mathrm{mM}$ sodium lactate, $0.022 \mathrm{~g} \mathrm{NaHCO}_{3} / 100 \mathrm{ml}$, plus leucine, lysine with or without methionine. Vectashield mounting medium and the ABC Vectastain kit were from Vector Laboratories (Burlingame, CA). Glutaraldehyde electron microscopic grade $(2 \%)$ was from Taab Laboratories (England), and Lowicryl K4M was from PolyScience Inc., (Warrington, PA). Scientiprep-2 was from Fisher Scientific, and photographic film (Biomax MR) used for autoradiography was from Kodak (Rochester, NY). $\left[{ }^{35} \mathrm{~S}\right]$ Methionine $(1160 \mathrm{Ci} / \mathrm{mmol})$ was from NEN Research Products (Boston, MA). All other chemicals were obtained commercially and were of the highest purity available.

\section{Purification of $\beta$-D-galactosidase and production of antiserum}

$\beta$-D-galactosidase (97 $\mathrm{kDa}$ form) was purified to apparent homogeneity from rat epididymal luminal fluid (9) and used for the production of antiserum by immunizing a female white rabbit by our published procedure (7). Affinity purified polyclonal antibody (IgG fraction) was prepared on a column of immobilized protein $G$ (Pharmacia LKB Biotechnology, Piscataway, NJ) using manufacturer's protocol. The IgG fraction was dialyzed against $50 \mathrm{mM}$ Tris- $\mathrm{HCl}$, pH 7.5 containing $0.15 \mathrm{M} \mathrm{NaCl}$ and concentrated (3-4 mg protein/ml) using Centricon 10 micro-concentrator from Amicon (Beverly, MA). The monospecific IgG fraction was prepared by applying the serum to a column of immobilized $\beta$-D-galactosidase (immobilized on Sepharose 4B) equilibrated with $50 \mathrm{mM}$ Tris- $\mathrm{HCl}$ buffer, $\mathrm{pH} 7.5$ containing $0.15 \mathrm{M} \mathrm{NaCl}$. The bound $\gamma$-globulin was eluted with the above buffer containing $7 \mathrm{M}$ urea, followed by dialysis and concentration as above. The affinity purified and monospecific antibodies were aliquoted, and stored frozen at $-75^{\circ} \mathrm{C}$. Rat epididymal $\beta$-D-galactosidase used as a carrier (unlabeled) enzyme during biosynthetic studies was partially purified from rat epididymis by acid and heat treatment (10). Briefly, epididymal homogenates $(10 \%$, w/v) were prepared at $4{ }^{\circ} \mathrm{C}$ in a solution containing $0.1 \mathrm{M}$ Tris- $\mathrm{HCl}, \mathrm{pH} 7.5$, and $0.15 \mathrm{M} \mathrm{NaCl}$ by homogenizing for 50 sec with a polytron homogenizer (Type PT 1020 3500; Brinkman Instruments, Westbury, NY) set at position 5. Sodium deoxycholate was added to a final concentration of $0.5 \%$ to the vigorously stirred homogenate to solubilize the lysosomal $\beta$-D-galactosidase. The $\mathrm{pH}$ of the homogenate was lowered to 4.8 by adding $1 \mathrm{M}$ acetic acid $(0.06 \mathrm{ml} / \mathrm{ml})$, and the mixture was heat treated by incubation at $56^{\circ} \mathrm{C}$ for $30 \mathrm{~min}$. Deoxycholate (which precipitated due to the acidic $\mathrm{pH}$ ) and denatured proteins were removed by centrifugation $(25,000 \mathrm{~g} / 30 \mathrm{~min})$. The supernatant was removed by aspiration, assayed for $\beta$-D-galactosidase activity using PNP- $\beta$-D-galactoside substrate at $\mathrm{pH} 3.5$. The partially purified enzyme (specific activity, 65 units/mg protein) was concentrated to a small volume $(\sim 2 \mathrm{ml})$ using a microconcentrator, aliquoted ( 2 units/aliquot), stored frozen at $-20^{\circ} \mathrm{C}$, and used as a source of carrier (unlabeled) enzyme.

\section{Isolation of testicular germ cells}

The protocol consists of the dissociation of the seminiferous tubules and epithelial cells of the testis followed by separation of mixed germ cells by unit gravity sedimentation on the basis of their size. The method, originally described by Romrell et al. (11), has been extensively used for many laboratory species (12-14) as well as a larger animal (15). The method described here was adopted from a published procedure of O'Brien for mice and rats (16). Rats ( 8 weeks old) were killed by $\mathrm{CO}_{2}$ asphyxiation. The testis, along with the epididymis and fat pad, was excised and perfused with enriched KrebsRinger bicarbonate medium (EKRB) through the testicular artery. The EKRB solution was prepared just before use by mixing stock solutions of EKRB salts, bicarbonate, glutamine-streptomycin-penicillin, essential and nonessential amino acids to a final concentration of $119.4 \mathrm{mM}$ $\mathrm{NaCl}, 4.8 \mathrm{mM} \mathrm{KCl}, 25.2 \mathrm{mM} \mathrm{NaHCO}, 1.2 \mathrm{mM} \mathrm{MgSO}_{4}, 7$ $\mathrm{H}_{2} \mathrm{O}, 1.3 \mathrm{mM} \mathrm{CaCl}$, $11.1 \mathrm{mM}$ glucose, $1 \mathrm{mM}$ sodium pyruvate, $6 \mathrm{mM}$ sodium L-lactate, $1 \mathrm{mM}$ glutamine, $100 \mu \mathrm{g}$ streptomycin/ml, $100 \mathrm{U}$ penicillin/ml, $10 \mathrm{ml}$ each of the essential and non-essential amino acid/ liter. The $\mathrm{pH}$ was adjusted to 7.0-7.2 by bubbling with a $5 \% \mathrm{CO}_{2}$ in air for 5- 
$10 \mathrm{~min}$.

\section{Sequential enzymatic dissociation of seminiferous tubules and epithelial cells}

The perfused testes were excised and their contents released by a small incision in the tunica albuginea. Mechanical dispersion of the seminiferous tubules should be avoided since it causes the formation of multinucleated germ cells. The detunicated testes were incubated in siliconised glass or Teflon Erlenmeyer flask in $65 \mathrm{ml}$ of collagenase solution (1 $\mathrm{mg} / \mathrm{ml}$ EKRB) under $5 \% \mathrm{CO}_{2}$ in air for $20 \mathrm{~min}$ at $33^{\circ} \mathrm{C}$ in a shaking water bath operated at 120 cycles $/ \mathrm{min}$. The dispersed seminiferous tubules were isolated by allowing them to sediment for 2-3 min under 5\% $\mathrm{CO}_{2}$ in air and decanting the supernatant. The process was repeated 2-3 times with $10 \mathrm{ml}$ EKRB to stop the reaction and to ensure removal of the dissociated interstitial cells (e.g., Leydig cells, peritubular myoid cells) and blood cells. This step is important for obtaining spermatogenic cells in high purity prior to their separation. The seminiferous tubules were then incubated in $50 \mathrm{ml}$ EKRB containing $0.5 \mathrm{mg}$ trypsin/ml and $1 \mu \mathrm{g}$ DNase/ml for $15 \mathrm{~min}$ using the above conditions. Cell aggregates which remained after trypsin treatment were dissociated gently by repeated pipetting for 3-5 min with a plastic Pasteur pipet. The reaction was stopped by the addition of $50 \mathrm{ml}$ of EKRB containing 0.5 $\mathrm{mg}$ soybean trypsin inhibitor/ml and agitation (3-5 $\mathrm{min}$ ). The cells were filtered through a $70 \mu \mathrm{m}$ nylon mesh. The filtered cells were pelleted by centrifugation at $400 \mathrm{~g} / 5 \mathrm{~min}$, and the pelleted cells were washed by suspending in EKRB buffer containing $0.5 \%$ BSA and centrifugation as above (2 washes). Finally, the washed cells were suspended in 20-25 $\mathrm{ml}$ of EKRB containing $0.5 \%$ BSA. The yield of spermatogenic cells prepared from two testes was usually 7.5 to $9 \times 10^{8}$ as counted by a hemocytometer on phase contrast microscope. Over $95 \%$ of the cells were viable as assessed by the exclusion of trypan blue.

\section{Separation of germ cells by unit gravity sedimentation}

The cell separation was carried out at $4^{\circ} \mathrm{C}$ for a total of 4 hours beginning from the loading of the cells and collection of the last fraction. The sedimentation chamber was initially loaded from the bottom through the cell-loading syringe with $\sim 50 \mathrm{ml}$ of EKRB to a level just above the baffle. The EKRB should completely fill the tubing leading from the syringe without any air bubbles. An aliquot containing 5-6 $\times 10^{8}$ germ cells suspended in EKRB supplemented with $0.5 \%$ BSA was loaded through the syringe in the sedimentation chamber at a flow rate of 10 $\mathrm{ml} / \mathrm{min}$. Immediately after introducing the cell suspension, the chamber was filled with $1200 \mathrm{ml}$ of a linear BSA (2$4 \%$ in EKRB at a flow rate of $10 \mathrm{ml} / \mathrm{min}$ adjusted with the $\mathrm{T}$-valve and later increased to $40 \mathrm{ml} / \mathrm{min}$. After the gradient loading was completed, the micrometering valve was closed and the cells were allowed to sediment. After $2 \mathrm{~h}$ and 40 min at $4^{\circ} \mathrm{C}$, fractions $(10 \mathrm{ml})$ were collected in disposable polystyrene tubes $(17 \times 100 \mathrm{~mm})$ at a rate of $40-42 \mathrm{sec}$ per tube. The tubes were centrifuged $(400 \mathrm{~g} / 5 \mathrm{~min})$ and the top $9 \mathrm{ml}$ of the supernatants aspirated, leaving $\sim 1 \mathrm{ml}$ in each tube. The presence of cells was confirmed by the appearance of the cell pellet and their quality and quantity assessed by examining cells in every fourth or fifth fraction using phase contrast microscopy (Figs. 1 and 2). Spermatocytes, which are the largest spermatogenic cells, were collected first followed by round spermatids of intermediate size and then condensed/elongated spermatids. The residual bodies were found only in the last few fractions. The fractions rich in spermatocytes, round spermatids, and condensed/elongated spermatids were pooled separately (Fig. 1), washed with EKRB and used for further studies.

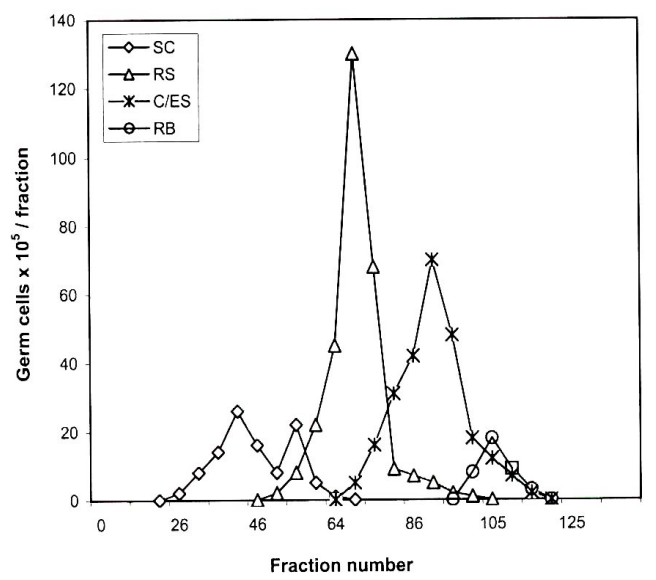

Fig. 1: The sedimentation profile of rat testicular germ cells following unit gravity sedimentation on a linear BSA gradient. Fractions $(10 \mathrm{ml})$ were collected from the bottom and their composition was examined using phase-contrast microscopy. Fractions were pooled as follows: spermatocytes (SC), fractions 25-56; round spermatids (RS), fractions 65-72; condensed/elongated spermatids (C/ES), fractions 84-99. Residual bodies (RB) were present in the last few fractions.

\section{Radiolabeling of spermatocytes and round spermatids.}

Enriched populations of viable (approximately 95\% viable as assessed by the Trypan blue exclusion test) 
spermatocytes $(>95 \%$ pure) and round spermatids $(>95 \%$ pure) were pooled and $1.5 \times 10^{7}$ cells $/ \mathrm{ml}$ were incubated in $3 \mathrm{ml}$ of methionine-free MEM supplemented with $0.4 \%$ BSA, non-essential amino acids, antibiotics (penicillin, 0.1 unit/ml; streptomycin, $0.1 \mathrm{mg} / \mathrm{ml})$, fungizone $(1 \mu \mathrm{g} / \mathrm{ml})$, $5 \mathrm{mM}$ sodium lactate as described (7). After $30 \mathrm{~min}$ at $34^{\circ} \mathrm{C}$, the methionine-depleted cells were centrifuged at 400 $\mathrm{g} / 5 \mathrm{~min}$ and the pelleted cells suspended in the above medium containing $\left[{ }^{35} \mathrm{~S}\right]$ methionine $(400 \mu \mathrm{Ci} / \mathrm{ml})$ and incubated at $34^{\circ} \mathrm{C}$ under $5 \% \mathrm{CO}_{2}$ in air. After $30 \mathrm{~min}$ of labeling (pulse), the cells were pelleted and washed four times by suspending each time in $2 \mathrm{ml}$ of PBS and centrifugation (400 g/5 min). The washed cells were either frozen (pulse) or suspended in $3 \mathrm{ml}$ of the above medium containing non-radioactive methionine and cultured for pulse-chase studies. At desired time interval (chase), the cells were washed as above and the pelleted cells were frozen.

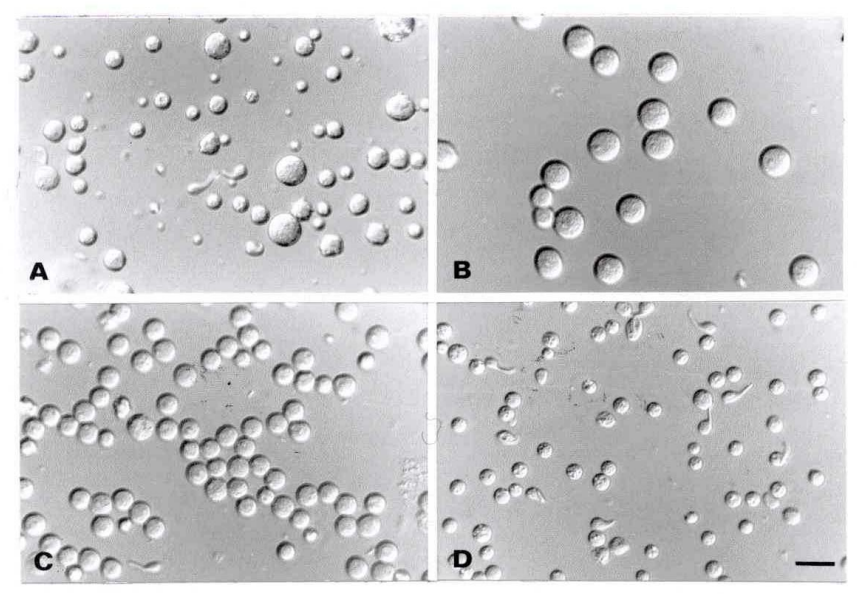

Fig. 2: Microscopic appearance of germ cells prepared from the rat testis. $\mathrm{A}$, mixed germ cells obtained after enzymatic dispersion of the testis; B, spermatocytes; C, round spermatids; and D, condensed/elongated spermatids. Other details are described in Materials and Methods and in the legend to Figure 1. Aliquots of mixed cells (A) or separated cells (B-D) were photographed using Nomarski differential interference contrast optics. Scale bar $=17 \mu \mathrm{m}$.

4. Extraction, immunoprecipitation, and SDSPAGE of $\left[{ }^{35}\right.$ S $]$ methionine-labeled $\beta$-Dgalactosidase.

The frozen cells were suspended in a small volume $(0.2 \mathrm{ml})$ of ice-cold $0.1 \mathrm{M}$ Tris- $\mathrm{HCl}$ buffer, $\mathrm{pH} 7.5$, containing 0.15 $\mathrm{M} \mathrm{NaCl}, 1 \%$ Triton $\mathrm{X}-100,0.5 \%$ sodium deoxycholate, and a protease inhibitor mixture $(2 \mu \mathrm{g}$ antipain $/ \mathrm{ml}, 0.1 \%$ aprotinin, $10 \mu \mathrm{g}$ benzamidine $/ \mathrm{ml}, 1 \mu \mathrm{g}$ chymostatin $/ \mathrm{ml}$, $1 \mu \mathrm{g}$ leupeptin/ml, and $1 \mu \mathrm{g}$ pepstatin/ml) as described (17).
The mixture was sonicated ( $3 \times 10$ second bursts on ice) in a Fisher sonicator set at speed 40, and centrifuged at $105,000 \mathrm{~g} / 30 \mathrm{~min}$. Supernatant was removed by aspiration and mixed with 2 units of the partially purified $\beta-D$ galactosidase carrier (see above), and $60 \mu \mathrm{g}$ of affinitypurified immune or preimmune IgG. Samples were incubated at $34^{\circ} \mathrm{C}$ for $30 \mathrm{~min}$ followed by overnight incubation at $4^{\circ} \mathrm{C}$ with gentle rocking. Following these incubations, the immunoprecipitates were collected by centrifugation $(8000 \mathrm{~g} / 10 \mathrm{~min})$. The immune/preimmune precipitates were washed by suspending in $0.1 \mathrm{M}$ Tris- $\mathrm{HCl}$ buffer, $\mathrm{pH} 7.5,0.15 \mathrm{M} \mathrm{NaCl}$, and $1 \% \mathrm{SDS}$ and centrifugation as above. The washed residues were mixed in Laemmli buffer containing $4 \mathrm{M}$ urea, boiled in a water bath $\left(100^{\circ} \mathrm{C} / 5 \mathrm{~min}\right)$, centrifuged in a microfuge, and the soluble peptides were electrophoresed on $7 \%$ polyacrylamide gels (SDS-PAGE) under reduced conditions (18). Gels were exposed to Biomax MR film, and the radioactive bands were revealed by processing after 1 week. Intensifying screens can be used to shorten the processing time.

In pulse-chase studies, after radiographic exposure, individual bands were cut from the gel and then placed in 1 ml of NCS solubilizer (diluted 9:1 with water) at room temperature overnight. Scintiprep- 2 in toluene $(10 \mathrm{ml}$ of $4 \%, \mathrm{v} / \mathrm{v})$ was then added and radioactivity was determined after $48 \mathrm{~h}$ at room temperature using liquid scintillation spectroscopy.

\section{Isolation of spermatozoa}

Following median laparotomy, the epididymis trimmed of adipose tissue was taken with the whole vas deferens and placed in a Petri dish. A small catheter (plastic tubing),

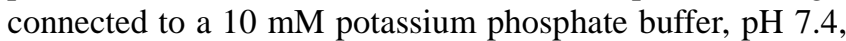
containing $0.15 \mathrm{M} \mathrm{NaCl}$ (PBS) and $25 \mathrm{mM}$ benzamidine was introduced into the vas deferens. The duct was then ligated around the catheter with a surgical thread and the proximal cauda was excised with a scissor. The flow rate of the buffer was adjusted by a pump to remove the cauda spermatozoa by retrograde flushing through the vas deferens. The fluid was centrifuged at $500 \mathrm{~g} / 10 \mathrm{~min}$, and the pelleted spermatozoa were suspended in desired buffer and used for immunocytochemistry or enzyme assay.

\section{Immunolocalization of $\beta$-D-galactosidase}

The $\beta$-D-galactosidase was immunolocalized using monospecific antibody (experimental) or preimmune IgG or immune (monospecific) IgG preabsorbed with a five-fold excess of purified $\beta$-galactosidase (negative controls) by three different protocols:

\section{Preparation and immunostaining of testicular}




\section{sections}

After rats were anesthetized, the tissues were cleared of blood by perfusion through the left ventricle with a saline solution $(0.9 \% \mathrm{NaCl})$ before they were perfused with Bouin's fixative (75\% saturated picric acid, $20 \%$ formol and $5 \%$ glacial acetic acid). The fixed testes were cut and immersed for $20 \mathrm{~h}$ in the same fixative after which the tissue pieces were dehydrated in graded ethanol and embedded in paraffin before thin sections $(\sim 5 \mu \mathrm{m})$ were prepared. The sections were freed from paraffin and hydrated through graded ethanol to PBS, pH 7.4. Endogenous peroxidase activity was quenched by incubation $(30 \mathrm{~min})$ in $0.03 \% \quad \mathrm{H}_{2} \mathrm{O}_{2}$ in methanol. Nonspecific binding sites were blocked (30 min) with $10 \%$ normal goat serum (NGS) in PBS. The sections were then incubated $\left(1 \mathrm{~h}\right.$ at $\left.37^{\circ} \mathrm{C}\right)$ with preimmune/monospecific $\mathrm{IgG}$ (5 $\mu \mathrm{g}$ protein $/ \mathrm{ml}$ of $10 \%$ NGS in PBS) in a humidified chamber, washed ( $3 \times 10 \mathrm{~min})$ in PBS before incubation (1 $\mathrm{h}$ at $\left.20^{\circ} \mathrm{C}\right)$ with a $1 / 200(\mathrm{v} / \mathrm{v})$ diluted goat anti-rabbit $\mathrm{IgG}$. The sections were washed as before and incubated $(30 \mathrm{~min})$ in avidin-biotin horseradish peroxidase complex according to the $\mathrm{ABC}$ kit protocol. The antigen was visualized by revealing the peroxidase activity with $0.05 \%$ diaminobenzidine tetrahydrochloride in Tris- $\mathrm{HC} 10.2 \mathrm{M}, \mathrm{pH}$ 7.5 and $0.02 \% \mathrm{H}_{2} \mathrm{O}_{2}$. After washing in distilled water to stop the reaction, the sections were dehydrated and mounted.

\section{Indirect immunofluorescence}

This method was used to examine the binding of monospecific or preimmune $\operatorname{IgG}$ to the isolated spermatogenic cells and cauda epididymal spermatozoa. The cells were suspended in PBS/1\% BSA and placed onto poly-L-lysine coated coverslips. The cells were allowed to adhere to the coverslips by keeping them in a humidified chamber for $15 \mathrm{~min}$ at $20^{\circ} \mathrm{C}$. After two washes in $\mathrm{PBS} / 0.1 \%$ BSA, the adherent cells were either included with IgG (intact cells) or permeabilized in methanol (15 min at $-20^{\circ} \mathrm{C}$ ) before interaction with the IgG. Drops of monospecific/preimmune (5 $\mu \mathrm{g}$ protein/ml $\mathrm{PBS} / 0.1 \% \mathrm{BSA}$ ) were placed on top of the cells and the coverslips kept in a humidified chamber $\left(60 \mathrm{~min}\right.$ at $\left.20^{\circ} \mathrm{C}\right)$. After three washes in $\mathrm{PBS} / 0.1 \% \mathrm{BSA}$, the cells were incubated in a dark humidified chamber $\left(60 \mathrm{~min}\right.$ at $\left.20^{\circ} \mathrm{C}\right)$ with $1 / 100$ diluted secondary antibody (FITC-labeled anti-rabbit goat $\operatorname{IgG}$ ). Following this incubation, the cells were washed in PBS, mounted with vectashield, sealed with nail polish, and observed under phase-contrast epifluorescence illumination or under a confocal microscope using Nomarski differential interference contrast optics.

\section{Immunoelectron microscopy}

After rats were anesthesized, the tissues were cleared of blood and fixed as above by perfusion through the left ventricle for $10 \mathrm{~min}$ with $1 \%$ glutaraldehyde in $0.1 \mathrm{M}$ cacodylate buffer, $\mathrm{pH}$ 7.3. Following this fixation, each testis and cauda epididymis was removed, cut into small pieces, and immersed in the above fixative for $50 \mathrm{~min}$ at room temperature. The tissues were dehydrated in graded solutions of dimethylformamide $(20 \mathrm{~min}$ each $)$ and progressively infiltrated under agitation with Lowicryl K4M according to Altmann et al. (19). Samples were then transferred to $6 \mathrm{~mm}$ diameter gelatin capsules filled with Lowicryl and closed. Polymerization was done for 4 days under indirect UV-light at $4^{\circ} \mathrm{C}$ and for one day at $20^{\circ} \mathrm{C}$. The capsule holder was placed at $30-40 \mathrm{~cm}$ from the UV source. All instructions for use of Lowicryl K4M were furnished by the supplier. Ultrathin sections were mounted on uncoated nickel grids and floated for $30 \mathrm{~min}$ on a drop of $20 \mathrm{mM}$ Tris- $\mathrm{HCl}$ buffered saline ( $\mathrm{pH} 7.8$ ) containing $0.15 \%$ BSA (TBS-BSA) to block non-specific binding sites and $0.04 \%$ glycine to reduce the free aldehyde groups. The sections were immediately incubated $\left(2\right.$ hours at $\left.20^{\circ} \mathrm{C}\right)$ with monospecific/preimmune IgG (5 $\mu \mathrm{g}$ protein/ml TBS-BSA). After being washed in TBS-BSA, the sections were incubated with gold-labeled secondary antibody at a dilution of 1:20 (v/v) in the above Tris-BSA buffer. The sections were stained with uranyl acetate $\left(20 \mathrm{~min}\right.$ at $\left.20^{\circ} \mathrm{C}\right)$ before electron microscopic observation.

\section{Enzyme assay}

Acid glycohydrolases were assayed by measuring the hydrolysis of PNP-glycopyranoside substrate at their optimum $\mathrm{pH}$ as below.

All enzymes were assayed by incubating the purified germ cells $\left(\sim 1 \times 10^{6}\right.$ cells/tube), appropriate substrate and Triton $\mathrm{X}-100(0.2 \%, \mathrm{v} / \mathrm{v})$ in a total volume of $0.5 \mathrm{ml}$ at their optimum $\mathrm{pH}$ as follows: $\alpha$-D-mannosidase, $5 \mathrm{mM}$ PNP $\alpha$ D-mannoside, $0.1 \mathrm{M}$ sodium acetate buffer, $\mathrm{pH} 4.4 ; \mathrm{N}$ acetyl $\beta$-D-glucosaminidase, $5 \quad \mathrm{mM} \quad$ PNP- $\beta-\mathrm{N}$ acetylglucosaminide, $0.1 \mathrm{M}$ sodium acetate buffer, $\mathrm{pH} 4.5$; $\beta$-D-glucuronidase, $1 \mathrm{mM}$ PNP- $\beta$-D-glucuronide, $0.1 \mathrm{M}$ sodium acetate buffer, $\mathrm{pH}$ 5.0; $\alpha$-L-fucosidase, $5 \mathrm{mM}$ PNP$\alpha$-L-fucoside, $0.1 \mathrm{M}$ sodium acetate buffer, $\mathrm{pH} 5.0$; and $\beta$ D-galactosidase, $5 \mathrm{mM}$ PNP- $\beta$-D-galactoside, $0.1 \mathrm{M}$ sodium citrate buffer, $\mathrm{pH}$ 3.5. After incubation for $1 \mathrm{~h}$ at $37^{\circ} \mathrm{C}$, the reaction was stopped by the addition of the glycine buffer containing $0.133 \mathrm{M}$ glycine, $0.067 \mathrm{M} \mathrm{NaCl}$, $0.083 \mathrm{M} \mathrm{Na}_{2} \mathrm{CO}_{3}$ adjusted to $\mathrm{pH} 10.7$ with $1 \mathrm{M} \mathrm{NaOH}(20)$. The amount of p-nitrophenol released was estimated by measuring the absorbance of the sample at $400 \mathrm{~nm}$, and comparing with standard curves. Enzyme or substrate controls were incubated concurrently and the corresponding readings were subtracted from that obtained with complete enzyme system (enzyme and substrate). One unit is the 
amount of enzyme that catalyzes the release of $1 \mu \mathrm{mol} p$ nitrophenol per $\mathrm{h}$ at $37^{\circ} \mathrm{C}$.

\section{RESULTS AND DISCUSSION}

Highly enriched populations of rat testicular germ cells were prepared by sequential enzymatic dissociation of rat testis. The treatment apparently preserves morphological and biochemical integrity of the dissociated germ cells $(12,13)$ which were purified by sedimentation based on their size. Three critical steps during cell separation are worth mentioning. First, loading of the mixed germ cells to the sedimentation chamber and the formation of a linear BSA gradient are important steps, and should be followed as described in the Materials and Methods. Second, the sedimentation time is very critical and should be established in a few preliminary runs. Finally, any vibrations to the sedimentation chamber during cell separation should be avoided to get reproducible results.

The purified diploid (spermatocytes) and haploid (round and elongated/condensed spermatids) cells were found to contain all five acid glycohydrolase activities (Table 1), a result suggesting that sperm-associated enzymes are first expressed in the diploid cells. The addition of a detergent (Triton X-100) in the assay mixture was to ensure that the cells were lyzed and that the PNP-substrates were in contact with the active site of the intracellular enzyme. In the absence of detergent, the enzyme activities were $50-70 \%$ of the values reported in Table 1 .

\section{TABLE 1. Glycohydrolase Activities In Rat Testicular Germ Cells And Spermatozoa ${ }^{1}$}

\begin{tabular}{|c|c|c|c|c|}
\hline \multirow[b]{2}{*}{ Enzyme $^{2}$} & \multicolumn{4}{|c|}{ Cells (milli units $/ 10^{6}$ Cells) } \\
\hline & $\mathrm{SC}$ & $\mathrm{RS}$ & $\mathrm{C} / \mathrm{ES}$ & $\mathrm{SP}^{3}$ \\
\hline$\beta$-N-Acetylglucosaminidase & $31.0 \pm 2.7$ & $7.4 \pm 0.2$ & $4.3 \pm 0.6$ & $220.8 \pm 12.4$ \\
\hline$\beta$-D-Galactosidase & $12.4 \pm 2.9$ & $6.6 \pm 0.4$ & $3.7 \pm 0.6$ & $43.5 \pm 4.4$ \\
\hline$\beta$-D-Glucuronidase & $1.6 \pm 0.2$ & $0.8 \pm 0.1$ & $0.5 \pm 0.1$ & $2.4 \pm 0.2$ \\
\hline$\alpha$-D-Mannosidase & $15.3 \pm 1.1$ & $7.5 \pm 0.5$ & $4.3 \pm 0.2$ & $18.1 \pm 1.0$ \\
\hline$\alpha$-L-Fucosidase & $44.8 \pm 2.7$ & $51.1 \pm 3.0$ & $21.5 \pm 0.4$ & ND \\
\hline
\end{tabular}

\footnotetext{
${ }^{1}$ The germ cells were prepared from rat testis, and spermatozoa from the distal cauda epididymidis as described under Materials and Methods. Fractions rich in spermatocytes (SC), round spermatids (RS), condensed/elongated spermatids (C/ES) were pooled (see Fig. 1) and centrifuged (400 g/5 min). The pelleted cells were suspended in PBS (approximately $100 \mathrm{x} 10^{6} \mathrm{cells} / \mathrm{ml}$ ) and used for enzyme assay. Values are average of four separate experiments in triplicate with \pm standard deviation (SD).

${ }^{2}$ All enzymes were assayed using PNP-glycoside substrates.

${ }^{3}$ Values reported for spermatozoa (SP) were calculated from a previous report (22).
}

The radiolabeling of cells in culture, and immunoprecipitation of the $\left[{ }^{35} \mathrm{~S}\right]$ methionine-labeled $\beta$-Dgalactosidase studies demonstrated that the enzyme was synthesized in spermatocytes and round spermatids in highmolecular weight precursor forms $(90 / 88 \mathrm{kDa})$ which undergo processing to lower molecular weight mature forms in a cell-specific manner. The net result is the formation of predominantly 64- and 62- kDa forms in spermatocytes and round spermatids, respectively. The protocol reported in this article can be adopted to study synthesis and processing of other proteins/glycoproteins in cell culture or to assess the effect of specific agents on spermatogenesis. For reproducible results, it is important to use highly specific antibody (preferably affinity purified IgG fraction). The antibody should first be titrated against a carrier antigen to establish the ratio of antibody needed for quantitative immunoprecipitation of a known amount of the unlabeled protein. Since the newly-synthesized radiolabeled antigen 
contributes very little protein/glycoprotein, the addition of a carrier antigen is highly recommended to ensure that the immune/preimmune precipitate forms a visible pellet during washing procedure.

We also examined the stage-specific localization of $\beta$ galactosidase during spermatogenesis and followed the successive formation of the acrosome during the cap and elongation phases of spermiogenesis. This was attempted using light and electron microscopic approaches in three different protocols. Data obtained from these approaches allow us to conclude that $\beta$-galactosidase is first seen in the late spermatocytes (pachytene spermatocytes). The immunopositive reaction was confined by light microscopy to granules dispersed in the cytoplasm around the nucleus (see Fig. 4 in reference 7). The presence of the enzyme in these cells is in agreement with the enzymatic assay data presented in Table 1 and the biosynthetic and processing studies with isolated spermatocytes. In round spermatids, the Golgi apparatus and the acrosomal vesicle (stages 2-3) or cap-like structure (stages 5-7) seen at one pole of the cell showed an intense immunopositive reaction in paraffin sections and isolated cells. As spermiogenesis continues, the reaction was seen over an enlarging cap-like structure extending from the base of the nucleus. It becomes confined to a distinct sickle-shaped structure which was also seen in testicular spermatozoa (Fig. 3).
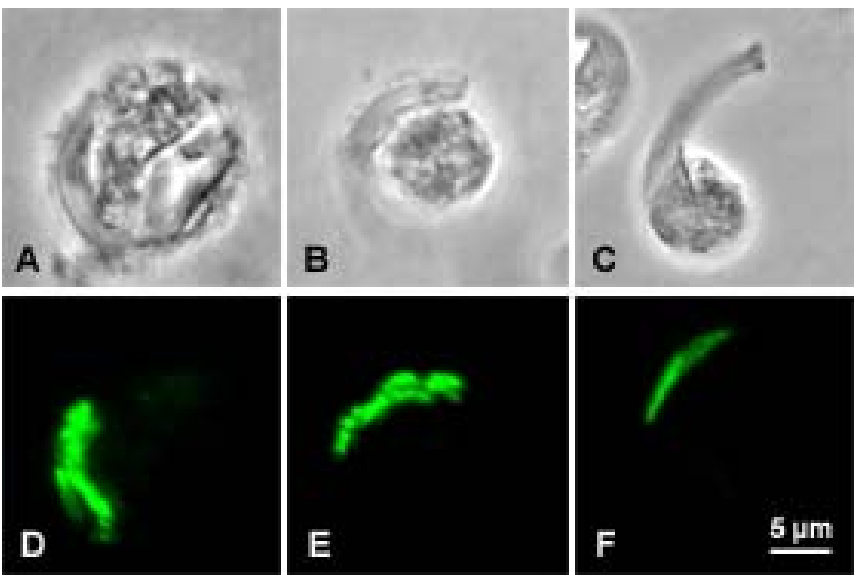

Fig. 3: Confocal micrographs showing immunolocalization of $\boldsymbol{\beta}$-galactosidase in the forming acrosome during spermiogenesis in the rat. The testicular germ cells were prepared and immunostained using anti- $\beta$-galactosidase (monospecific $\mathrm{IgG}, 5 \mu \mathrm{g}$ protein/ml) as primary antibody and FITC-labeled anti-rabbit goat $\mathrm{IgG}$ as secondary antibody as described in Materials and Methods.
Various phases of acrosome formation were photographed with a confocal microscope using Nomarski differential interference contrast optics (A-C) and immunofluorescence (D-F). Note the presence of intense fluorescence in the forming acrosome of steps 9 (A \& D), 12 (B \& E) and 15 (C \& F) elongated spermatids. The absence of a flagellum is due to its loss during preparation of the spermatogenic cells by enzymatic disruption of the testis.

At the ultrastructural level, the enzyme was visualized by the presence of gold particles in the Golgi apparatus, Golgiassociated vesicles and lysosome-like structures present within the spermatocytes and early round spermatids. The immunolabeling was obvious in the proacrosomal granules present in the trans-Golgi region, the acrosomal vesicles, and the head cap of round spermatids. By following the immunolocalization of $\beta$-galactosidase during the elongation and maturation phases of spermiogenesis, the gold particles were seen in the head cap of elongated spermatids and became confined to the acrosomal cap of maturing spermatids and spermatozoa (see Fig. 6 in reference 7). This localization is similar to our published reports with $\beta$-glucuronidase (21), another exoglycohydrolase. The distribution of the two enzymes showed the successive formation of the acrosome during the progressive transformation of the spermatids into spermatozoa with fully developed acrosome. Thus, glycohydrolases can be used as markers to examine acrosome formation.

It is important to emphasize that immunocytochemical approaches are qualitative and detect the antigen when the local concentration is reasonably high. Thus a high titer antibody is needed to detect low amounts of glycohydrolases present in the germ cells. In addition, the preservation of the antigenic site(s) during tissue (cell) fixation and processing of the tissue is an important factor which may have an influence on the immunopositive/immunonegative results. It is highly recommended to establish the optimal conditions of antibody concentration and incubation time to determine non-specific background staining. Also, samples (tissue sections or isolated cells) should be incubated in the presence of preimmune and/or immune IgG preabsorbed with an excess of purified enzyme to establish negative staining (negative controls).

\section{ACKNOWLEDGEMENTS}

The excellent editorial assistance of Mrs. Loreita Little and Ms. Lynne Black is gratefully acknowledged. We acknowledge many contributions of Dr. Marjorie Skudlarek, and assistance of Mr. Philippe Nguyen with computer graphics. The work presented here is supported in part by grants HD25869 and HD34041 from the National Institute of Child Health and Human Development. 


\section{REFERENCES}

1. de Duve C. The lysosome. Sci. Am. 1963; 208: 64-72.

2. de Duve C. The lysosome in retrospect. In: Dingle JD, Fell HB, editors. Lysosomes in Biology and Pathology. 1969:Vol 1, 3-19.

3. Abou-Haila A, Tulsiani DRP. Mammalian sperm acrosome: formation, contents and function. Arch. Biochem. Biophys. 2000; 379: 173-182.

4. Tulsiani DRP, Abou-Haila A, Loeser CR, Pereira, BMJ. The biological and functional significance of the sperm acrosome and acrosomal enzymes. Exp. Cell Res. 1998; 240: 151-164.

5. Couzelman E, Sandhoff K. Glycolipid and glycoprotein degradation. Adv. Enzymol. Relat. Areas Mol. Biol. 1987; 60: 89-216.

6. Pereira BMJ, Abou-Haila A, Tulsiani DRP. Rat sperm surface mannosidase is first expressed on the plasma membrane of testicular germ cells. Biol. Reprod. 1998; 59: 1288-1295.

7. Skudlarek MD, Abou-Haila A, Tulsiani DRP. Rat spermatogenic cell $\beta$-D-galactosidase: characterization, biosynthesis, and immunolocalization. Exp. Cell Res. 2000; 261: 139-149.

8. Grootegoed JA, Janson R, van der Molen HD. Effect of glucose on ATP dephosphorylation in rat spermatids. J. Reprod. Fertil. 1996 ;77: 99-107.

9. Tulsiani DRP, Skudlarek MD, Araki Y, Orgebin-Crist M-C. Purification and characterization of two forms of $\beta$-D-galactosidase from rat epididymal fluid: evidence for their role in the modification of sperm plasma membrane glycoprotein(s). Biochem. J. 1995; 305: 41-50.

10. Skudlarek MD, Swank RT. Biosynthesis of two lysosomal enzymes in macrophages. J. Biol. Chem. 1979; 254: 9939-9942.

11. Romrell LJ, Bellve AR, Fawcett DW. Separation of mouse spermatogenic cells by sedimentation velocity: A morphological characterization. Dev. Biol. 1976; 49: 119-132.

12. Bellve AR, Millette CF, Bhatnagar YM, O'Brien DA. Dissociation of the mouse testis and characterization of isolated spermatogenic cells. J. Histochem. Cytochem. 1977; 2: 480-494.

13. Bellve AR, Cavicchia JC, Millette CF, O'Brien DA, Bhatnagar YM, Dym M. Spermatogenic cells of the prepubertal mouse. Isolation and morphological characterization. J. Cell Biol. 1977; 74: 68-85.

14. Meistrich ML. Separation of spermatogenic cells and nuclei from rodent testes. Methods Cell Biol. 1977; 15: 15-54.

15. Loir M, Lanneau M. Separation of mammalian spermatids. Methods Cell Biol. 1977; 15: 55-77.

16. O'Brien DA. Isolation, separation and short-term culture of spermatogenic cells. Methods Toxicol. 1993;
3A: 246-264.

17. Shur BD, Neely CA. Plasma membrane association, purification, and partial characterization of mouse $\beta-1$, 4-galactosyltransferase. J. Biol. Chem. 1988; 263: 17706-17714.

18. Laemmli UK. Cleavage of structural proteins during the assembly of the head of bacteriophage $\mathrm{T}_{4}$. Nature 1977; 227: 680- 685.

19. Altmann LG, Schneider BG, Papermaster DS. Rapid embedding of tissues in Lowicryl K4M for immunoelectron microscopy. J. Histochem. Cytochem.1984; 32: 1217-1223.

20. Tulsiani DRP, Buschiazzo HO, Tolbert B, Touster OT. Changes in plasma hydrolase activities in hereditary and streptozotocin-induced diabetes. Arch. Biochem. Biophys. 1977; 181: 216-227.

21. Abou-Haila A., Fouquet J-P, Tulsiani DRP. Characterization and immunolocalization of $\beta-D$ glucuronidase in mouse testicular germ cells and spermatozoa. Exp. Cell Res. 1999: 247: 48-60.

22. Skudlarek MD, Tulsiani DRP, Nagdas SK, OrgebinCrist M-C. $\beta$-D-galactosidase of rat spermatozoa: subcellular localization, substrate specificity, and molecular changes during epididymal maturation. Biol. Reprod. 1993; 49: 204-215. 